Al-Azhar Bull. Sci. Vol. 19, No. 1 (June.): pp. 269-281, 2008.

\title{
OPEN-CIRCUIT AND POTENTIODYNAMIC STUDY ON THE ELECTROCHEMICAL BEHAVIOR OF TIN ELECTRODE IN SULPHURIC ACID AND SODIUM HYDROXIDE SOLUTIONS
}

R. M. ABOU SHAHBA, A. S. I. AHMED, E. M. ATTIA AND A. E. ELSHENNAWY

Chemistry Department, Faculty of Science (for Girls), AL-Azhar University, Cairo, Egypt.

\begin{abstract}
The electrochemical behavior of tin electrode in $\mathrm{H}_{2} \mathrm{SO}_{4}$ and $\mathrm{NaOH}$ solutions is studied in details using open- circuit potential measurements and potentiodynamic polarization techniques. The identification of the elements present in the surface of specimen after immersion in the two test solutions is performed using an energy dispersive $\mathrm{X}$-ray analysis (EDX).

Open- circuit potential measurements show that for tin electrode in low concentrations of $\mathrm{H}_{2} \mathrm{SO}_{4}$ and $\mathrm{NaOH}$ solutions the passivity was increased with dilution. At higher concentrations, dissolution of the pre-immersion oxide film occurs in which the corrosivety of $\mathrm{NaOH}$ is higher than that of $\mathrm{H}_{2} \mathrm{SO}_{4}$ solutions. Passivation of tin in $\mathrm{NaOH}$ solutions appears to take place in two steps. The first involves formation of $\mathrm{SnO}$ or $\mathrm{Sn}(\mathrm{OH})_{2}$, in the second step oxidation to $\mathrm{Sn}(\mathrm{OH})_{4}$ takes place.

Potentiodynamic polarization techniques illustrate that the dissolution of tin in sulphuric acid occurs through the participation of both $\mathrm{OH}^{-}$and $\mathrm{SO}_{4}{ }^{2-}$ ions through an intermediate of $\left(\mathrm{SnHSO}_{4} \mathrm{OH}\right)$ species. The potentiodynamic curves for tin in sodium hydroxide solutions exhibits an active/passive transition. The active dissolution region involves two anodic peaks prior to permanent passivity. The first anodic peak is due to the formation of $\mathrm{Sn}(\mathrm{OH})_{2}$ while the second peak corresponded to the formation of $\mathrm{Sn}(\mathrm{OH})_{4}$ in addition to the formation of the soluble stannate ions. Dehydration of unstable $\mathrm{Sn}(\mathrm{OH})_{4}$ to the stable $\mathrm{SnO}_{2}$ can occur on the tin electrode during the potential sweep to positive direction. Increasing concentrations of $\mathrm{H}_{2} \mathrm{SO}_{4}$ and $\mathrm{NaOH}$ solutions led to enhance the corrosion current ( $\mathrm{i}_{\text {corr. }}$ ), and corrosion potentials $\left(\mathrm{E}_{\text {corr }}\right)$ shift towards more negative values. $\mathrm{EDX}$ analysis showed that $\mathrm{Sn} \%$ present on the surface of tin electrode in $1 \mathrm{M}$ of each of $\mathrm{NaOH}$ and $\mathrm{H}_{2} \mathrm{SO}_{4}$ solutions was 91.82 and 83.52 respectively.
\end{abstract}

\section{Introduction}

Tin is used to best advantage in combination with other metals, in alloys ${ }^{(1-4)}$ or protective coatings ${ }^{(5-7)}$. Bronzes, which are copper-tin-base alloys, are used in bearings, valves, and pipe settings as well as in traditional applications such as bill making ${ }^{(\mathbf{8 9})}$. Electrochemical techniques have brought valuable information on the growth kinetics and electronic properties of the passive oxide film. Particularly, 
classical electrochemical techniques such as cyclic voltammetry, electrochemical impedance spectroscopy, potentiostatic, potentiodynamic, galvanostatic and galvanodynamic are still useful tools to investigate passive film formation, surface chemical equilibria as well as film electronic properties ${ }^{(\mathbf{1 0})}$. The inhibitions of corrosion of Sn are the subject of tremendous technological importance due to the increased industrial applications of this metal. The influence of some organic acids was studied ${ }^{(11-18)}$. Inorganic and halogen acids such as $\mathrm{HCl}, \mathrm{HNO}_{3}, \mathrm{H}_{2} \mathrm{SO}_{4}$ and $\mathrm{H}_{3} \mathrm{PO}_{4}$ are also studied. ${ }^{(19-21)}$. A wide studied in different alkaline solutions had take place ${ }^{(22,23)}$. Anodic polarization in $\mathrm{H}_{2} \mathrm{SO}_{4}$ resulted in a dark-brown film on the $\mathrm{Sn}$ electrode (apparently $\left.\mathrm{SnO}_{2}\right)^{(24)}$. Primary passivity of tin is attained in $\mathrm{NaOH}$ solutions when the metal is covered with a film of $\mathrm{Sn}(\mathrm{OH})_{2}$ or $\mathrm{SnO}$. Permanent passivity sets in when $\mathrm{Sn}(\mathrm{OH})_{4}$ forms as a continuous layer on the electrode surface ${ }^{(25,26)}$. The pitting sensitivity of tin in a synthetic medium similar to industrial water was not affected by $\mathrm{pH}$ variation ${ }^{(27)}$. Addition of oxo-anions to the synthetic medium leads to retard a breakdown of passivation and the inhibition of pitting process of tin ${ }^{(28)}$. The object of the present work is to study the anodic behavior of tin electrode in $\mathrm{H}_{2} \mathrm{SO}_{4}$ acid and $\mathrm{NaOH}$ solutions by open-circuit potential measurements and potentiodynamic polarization method.

\section{Experimental Materials}

The electrical circuit, electrolytic cell and the details of the experimental procedures are essentially the same as those described elsewhere ${ }^{(\mathbf{1 7})}$. The electrode used in the present study was spectroscopically pure tin rod electrode $(99.999 \%$ pure) with an apparent exposed area of $2 \mathrm{~cm}^{2}$. Tin rod was fixed to glass tubing with araldite adhesive. The electrical contact was made through a thick copper wire soldered to the inner side of the electrode. Prior to each experiment, the surface of the working electrode was performed by polishing with different grades emery papers, then diamond paste $(1 \mu \mathrm{m})$, washing by distilled water, drying and quickly inserted in the cell. The counter electrode was a platinum sheet. The potentials were recorded relative to a saturated calomel electrode (SCE).

\section{Adopted techniques}

Open-circuit potential measurements

The potential of tin electrode was measured against saturated calomel electrode (SCE) in different concentrations of test solutions ranging from $\left(10^{-5}-2 \mathrm{M}\right)$. All measurements were carried out in conventional glass cell at $\left(25 \pm 2^{\circ} \mathrm{C}\right)$. The potential 
was recorded as a function of time till steady - state values were reached by using electronic multimeter (Type E scord- EDM-2116).

\section{Potentiodynamic polarization measurements}

The polarization scans were performed with electronic potentiostate (Volt Lab PGZ 301Dy-namic EIS Voltammetry). The anodic E/I curves for all solutions were swept from $-1.5 \mathrm{~V}$ to $+1.5 \mathrm{~V}$ at scan rate $20 \mathrm{mV} / \mathrm{s}$. All measurements were performed in freshly prepared solutions at room temperature $\left(25 \pm 2^{\circ} \mathrm{C}\right)$.

Energy dispersive $X$-ray analysis (EDX).

The apparatus is model Brukey axs - $\Delta 8$ Advance and having time constant 2 seconds, and the range count per second is $2 \times 10^{3}$. During $\mathrm{X}$ - ray diffraction analysis, the X- ray beam falls on the plane of the crystal, after reflection, the beam can be detected and converted to peaks. The intensity of the peaks can give an idea about the percentage abundance of the different compounds.

\section{Results and Discussion}

\section{Open-circuit potential measurements:}

The behavior of tin electrode in different concentrations of $\mathrm{H}_{2} \mathrm{SO}_{4}$ and $\mathrm{NaOH}$ solutions was studied (Figures 1and 2). In low concentrations of $\mathrm{H}_{2} \mathrm{SO}_{4}\left(10^{-5}\right.$ to $\left.5 \times 10^{-4} \mathrm{M}\right)$ and $\mathrm{NaOH}\left(10^{-5}\right.$ and $\left.10^{-4} \mathrm{M}\right)$, the potential was shifted with time towards more positive values. This was in accordance with Evans ${ }^{(29)}$ where the oxide film was self- healing. Thus at low concentrations, the passivity increased with decreasing concentration, and the potential- time curves are characterized by a rapid rise in potential followed by steady state potential values $\left(E_{S S}\right)$. The steady state portion at these low concentrations might be attributed to the formation of stannic oxide $\left(\mathrm{SnO}_{2}\right)$ on the electrode surface. This increases the resistance of anodic area and led to passivation. However, at higher concentrations of $\operatorname{acid}\left(10^{-2}\right.$ to $\left.2 \mathrm{M}\right)$ and base $\left(5 \times 10^{-4}\right.$ to $\left.2 \mathrm{M}\right)$ solutions, the potential drifted with time towards more negative values denoting the destruction of the pre-immersion oxide film formed on the surface of the electrode.

Within the whole test solutions and concentrations, the immersion potential values lay negative side of the hydrogen/ hydrogen ion electrode system. This may indicate that the nature of the cathodic reaction occurring at the electrode surface is mainly hydrogen ion discharge (Equation 1) and the depolarization effect of oxygen was less manifested. 




Figure (1): Variation of open- circuit potential of tin electrode in $\mathrm{H}_{2} \mathrm{SO}_{4}$ solutions of various concentrations as a function of time



Figure (2): Variation of open-circuit potential of tin electrode in $\mathrm{NaOH}$ solutions of various concentrations as a function of time

$$
2 \mathrm{H}^{+}+2 \mathrm{e}^{-} \longrightarrow \mathrm{H}_{2}
$$

Figure 3 demonstrated the variation of the steady state potentials, $\mathrm{E}_{\mathrm{SS}}$, with the logarithm of the molar concentration of test solutions. Invariably straight lines are obtained satisfying the equation:

$$
\mathrm{E}_{\mathrm{SS}}=(\mathrm{a})-(\mathrm{b}) \log \mathrm{C}
$$


where; (a) and (b) are constants depending on the type of test solutions. In equation 2, (a) represented the potentials of $1 \mathrm{M}$ concentration, being -403 , and $-1269 \mathrm{mV}$ for $\mathrm{H}_{2} \mathrm{SO}_{4}$ and $\mathrm{NaOH}$ solutions respectively.

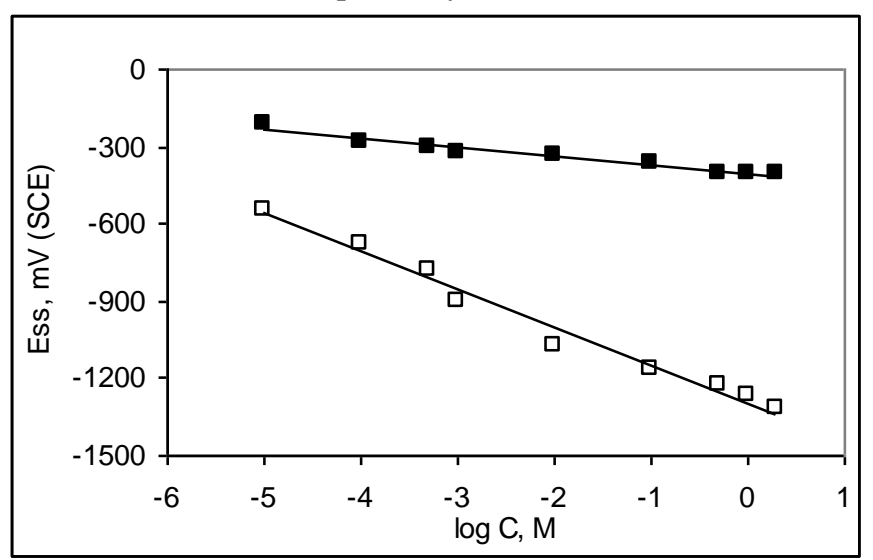

Figure (3): $\mathrm{E}_{\mathrm{ss}}-\log \mathrm{C}$ relations for: $-\mathrm{H}_{2} \mathrm{SO}_{4}$ and $\square \mathrm{NaOH}$ solutions

According to the change of the steady state potentials with the logarithmic concentration, the studied solutions retarded the corrosion of tin electrode as the concentration decreased. The more negative values of steady state potential, the more aggressive is the corresponding solution. Subsequently the corrosivety of $\mathrm{NaOH}$ solution is assumed to be higher than that of $\mathrm{H}_{2} \mathrm{SO}_{4}$ solution.

Tin will resist corrosion perfectly in slightly alkaline solutions, while it will be corroded in highly alkaline solutions ${ }^{(30)}$. However, tin begins to corrode in alkaline solutions only when the $\mathrm{pH}$ is sufficiently high to dissolve the oxide film $\left(\mathrm{SnO}_{2}\right)$ already existing on the metal ${ }^{(24)}$.

A plot of steady - state potential values $\mathrm{E}_{\mathrm{SS}}$ as a function of $\mathrm{pH}$ of the alkaline solution shows a straight line and $\mathrm{E}_{\mathrm{SS}}$ shift to more negative values by increasing the $\mathrm{pH}$ of solution (Figure 4). The straight line was found to follow the following relationship:

$$
\mathrm{E}_{\mathrm{SS}}=\alpha-\beta \mathrm{pH}
$$

Where $\alpha$ is the $\mathrm{pH}$ independent potential value of $\mathrm{E}_{\mathrm{SS}}$ obtained by the extrapolation of the linear relation to $\mathrm{pH}=0 . \quad \beta$ is the slope of the linear relation presented in the Figure. The value of $\alpha$ was found to be equal to $1.1 \mathrm{~V}$ for $\mathrm{Sn}$ electrode. This extrapolated value of the constant $\alpha$ is an indication that the metal surface is covered by a barrier film which consists most probably of a mixed oxide. 
According to the familiar Nernst equation, a $\mathrm{pH}$ indicator electrode will have a potential, which would be given by:

$$
\mathrm{E}=\mathrm{E}_{\mathrm{o}}-\frac{0.059 \mathrm{pH}}{\mathrm{n}}
$$

Where $\mathrm{E}$ is the steady state potential of that electrode at $25^{\circ} \mathrm{C}, \mathrm{E}_{\mathrm{o}}$ is the $\mathrm{pH}$ independent standard electrode potential of the electrode reaction. The value of $n$ corresponds to the number of electrons involved in the electrochemical process. For $\mathrm{Sn}$ electrode the slope of the $\mathrm{E}_{\mathrm{SS}} \mathrm{vs}$. $\mathrm{pH}$ linear relation amounts to $0.182 \mathrm{~V} / \mathrm{pH}$. In regions where the $\mathrm{OH}^{-}$ions are accessible to the electrode surface, solvation of the electrode occurs and deviation from the $n=1$ process is observed. Substituting the values obtained from the linear relation in Figure 4, then

$$
\mathrm{E}_{\mathrm{SS}}=1.1-0.182 \mathrm{pH}
$$

This means that the number of electrons $\mathrm{n}$ is equal to $\sim 0.3$. Equation (5) is not identical with any of the equations given in the literature for the Sn /aqueous solution system. Most likely the electrode potential represents a mixed potential.

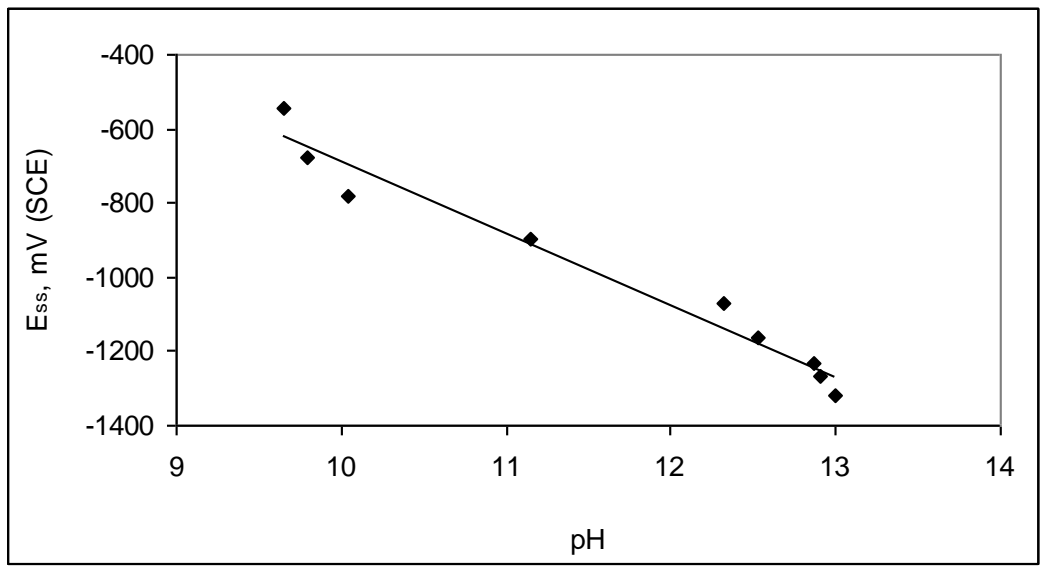

Figure (4): Steady state potential of Sn electrode as a function of $\mathrm{pH}$ of the $\mathrm{NaOH}$ solutions

The passivation of tin in slightly alkaline solutions appears to take place in two steps. The first step undoubtedly involves $\mathrm{SnO}$ or $\mathrm{Sn}(\mathrm{OH})_{2}$ (black in color) but from the available thermodynamic data it was not possible to distinguish between the two reactions. In the second step oxidation to $\operatorname{Sn}(\mathrm{OH})_{4}$ take place which remains stable, until it probably breaks down into metastannic acid just prior to the commencement of oxygen evolution. The proposed mechanism may be ${ }^{(31)}$ : 


$$
\begin{aligned}
& \mathrm{Sn}+2 \mathrm{OH}^{-} \longrightarrow \mathrm{SnO}+\mathrm{H}_{2} \mathrm{O}+2 \mathrm{e}^{-} \\
& \mathrm{SnO}+2 \mathrm{OH}^{-}+\mathrm{H}_{2} \mathrm{O} \longrightarrow \mathrm{Sn}(\mathrm{OH})_{4}+2 \mathrm{e}^{-}
\end{aligned}
$$

or

$$
\begin{aligned}
& \mathrm{Sn}+2 \mathrm{OH}^{-} \longrightarrow \mathrm{Sn}(\mathrm{OH})_{2}+2 \mathrm{e}^{-} \\
& \mathrm{Sn}(\mathrm{OH})_{2}+2 \mathrm{OH}^{-} \longrightarrow \mathrm{Sn}(\mathrm{OH})_{4}+2 \mathrm{e}^{-}
\end{aligned}
$$

\section{Potentiodynamic polarization measurements}

Potentiodynamic behavior of tin electrode in sulphuric acid solutions

The E- I curves of Figure (5) illustrated clearly that the current increased sharply by increasing the potential at high concentrations of acid. In low concentrations, the current increased smoothly by increasing potential to the limiting current corresponding to the passive region. With respect to $\left(\mathrm{H}^{+}\right)$and $\left(\mathrm{SO}_{4}^{--}\right)$ions, it was suggested that $\left(\mathrm{SO}_{4}^{--}\right)$ion participated in the tin dissolution reaction.

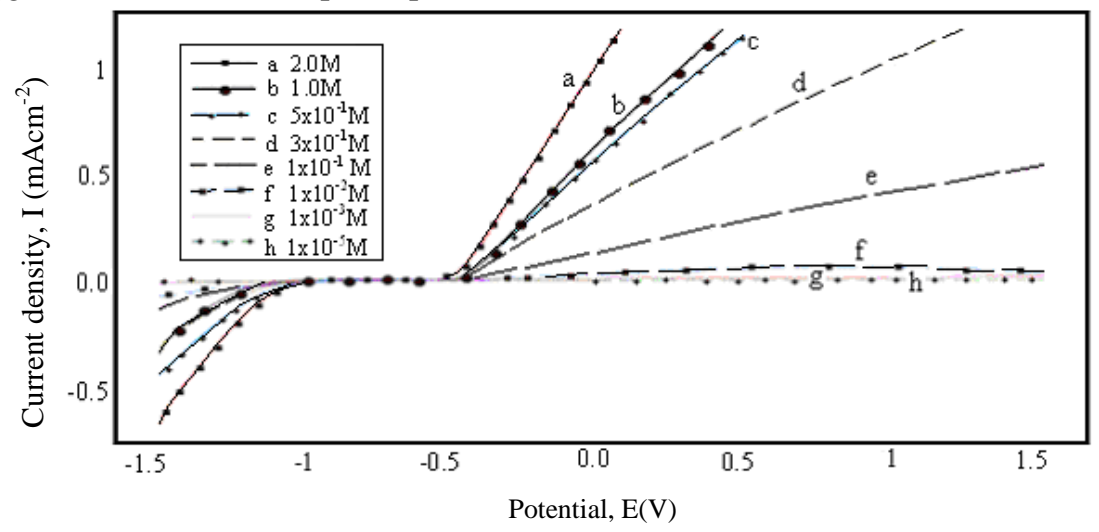

Figure (5): Potentiodynamic anodic and cathodic polarization curves of tin electrode in different concentrations of $\mathrm{H}_{2} \mathrm{SO}_{4}$ acid solutions

In sulphuric acid solutions, the $\mathrm{Sn}^{2+}$ ion may forms complex anions. There is some dispute about the nature of these anions. Both $\mathrm{Sn}\left[\mathrm{Sn}\left(\mathrm{SO}_{4}\right)_{2}\right]$ and $\mathrm{H}_{2} \mathrm{Sn}_{2}\left(\mathrm{SO}_{4}\right)_{3}$ groups have been proposed ${ }^{(32)}$. Another authors ${ }^{(33)}$ proposed $\mathrm{Sn}(\mathrm{OH})^{+}$ion and $\left[\mathrm{Sn}(\mathrm{OH}) \mathrm{SO}_{4}\right]^{-}$complexes. There are an equilibrium between $\mathrm{Sn}^{2+}$ and $\left[\mathrm{Sn}(\mathrm{OH})_{4}\right]^{2-}$ in dilute sulphuric acid ${ }^{(32)}$. These results indicated that both $\mathrm{OH}^{-}$and sulphate groups could interfere with the electrode reaction.

The reaction scheme for anodic tin dissolution can be given as ${ }^{(\mathbf{3 4})}$ :

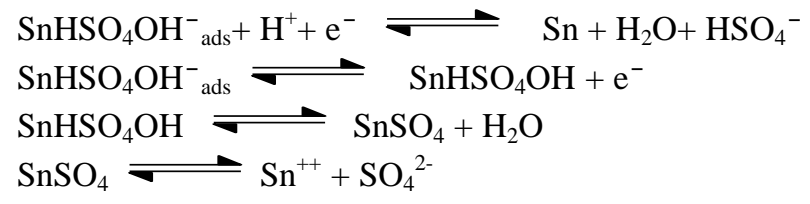


From the above reactions, it can be concluded that the tin dissolution in sulphuric acid occurs through the participation of both $\mathrm{OH}^{-}$and $\mathrm{SO}_{4}{ }^{2-}$ ions through an intermediate of $\left(\mathrm{SnHSO}_{4} \mathrm{OH}\right)$ species ${ }^{(34)}$. Table 1 illustrated the electrochemical parameters calculated from Tafel relations in sulphuric acid solutions. Decreasing concentration led to decrease of the corrosion rate. Also the corrosion potential shifted to more positive values indicating passivation with dilution.

Table(1): The electrochemical parameters of tin electrode in different concentrations of $\mathrm{H}_{2} \mathrm{SO}_{4}$ solutions.

\begin{tabular}{|c|c|c|c|c|c|}
\hline \multirow{2}{*}{$\begin{array}{c}\text { Conc. } \\
\text { M }\end{array}$} & \multirow{2}{*}{$\begin{array}{c}\mathbf{E}_{\text {corr. }} \\
\mathbf{m V}(\text { SCE })\end{array}$} & \multirow{2}{*}{$\underset{\mathrm{mA} / \mathrm{cm}^{2}}{\mathbf{i}_{\text {corr. }}}$} & \multicolumn{2}{|c|}{$\begin{array}{c}\text { Tafel Slopes (mV/ } \\
\text { decade) }\end{array}$} & \multirow{2}{*}{$\begin{array}{l}\text { Corrosion } \\
\text { rate } \mathbf{m m} / \mathbf{y}\end{array}$} \\
\hline & & & $\mathbf{B}_{\mathbf{a}}$ & $\mathbf{B}_{\mathrm{c}}$ & \\
\hline 2.0 & -979.0 & 0.700 & 153 & -104 & 7.98 \\
\hline 1.0 & -970.6 & 0.660 & 426 & -123 & 7.92 \\
\hline $5 \times 10^{-1}$ & -843.4 & 0.300 & 131 & -114 & 3.56 \\
\hline $3 \times 10^{-1}$ & -824.0 & 0.300 & 274 & -125 & 3.40 \\
\hline $1 \times 10^{-1}$ & -563.4 & 0.330 & 63.0 & -685 & 3.92 \\
\hline $1 \times 10^{-2}$ & -517.0 & 0.310 & 125 & -420 & 3.68 \\
\hline $1 \times 10^{-3}$ & -486.9 & 0.274 & 292 & -113 & 3.63 \\
\hline $1 \times 10^{-5}$ & -474.0 & 0.195 & 400 & -328 & 2.32 \\
\hline
\end{tabular}

Potentiodynamic behavior of tin electrode in sodium hydroxide solutions

Figure 6 represents typical potentiodynamic E/I response for a tin electrode in different concentrations of $\mathrm{NaOH}\left(1 \times 10^{-5}-2 \mathrm{M}\right)$ solutions. The active dissolution region involves two anodic peaks prior to permanent passive region.

The first anodic peak which located at $\approx-900 \mathrm{mV}$ is due to the formation of $\mathrm{Sn}(\mathrm{OH})_{2}$ according to the reaction ${ }^{(35)}$ :

$$
\mathrm{Sn}+2 \mathrm{OH}^{-} \longrightarrow \mathrm{Sn}(\mathrm{OH})_{2}+2 \mathrm{e}^{-}
$$

Two further reactions may take place within the potential range of the first peak; one yielding dehydration of $\mathrm{Sn}(\mathrm{OH})_{2}$ and formation of $\mathrm{SnO}$ :

$$
\mathrm{Sn}(\mathrm{OH})_{2} \longrightarrow \mathrm{SnO}+\mathrm{H}_{2} \mathrm{O}
$$

and the other involving the formation of soluble stannite species,

$$
\mathrm{Sn}+3 \mathrm{OH}^{-} \longrightarrow \mathrm{HSnO}_{2}^{-}+\mathrm{H}_{2} \mathrm{O}+2 \mathrm{e}^{-}
$$




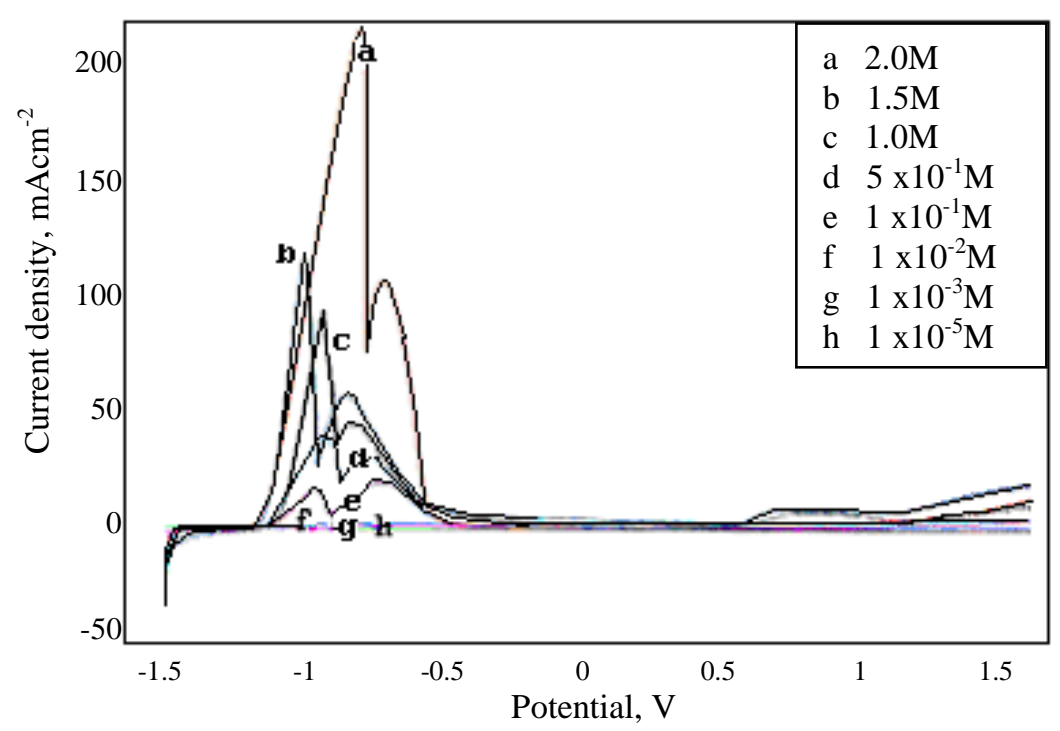

Figure (6): Potentiodynamic anodic and cathodic polarization curves of tin Electrode in different concentrations of $\mathrm{NaOH}$ solutions

The second anodic peak located at $\approx-730 \mathrm{mV}$ corresponding to the formation of $\mathrm{Sn}(\mathrm{OH})_{4}$ according to the following reactions ${ }^{(35)}$ :

$$
\mathrm{Sn}(\mathrm{OH})_{2}+2 \mathrm{OH}^{-} \longrightarrow \mathrm{Sn}(\mathrm{OH})_{4}+2 \mathrm{e}^{-}
$$

and/or

$$
\mathrm{SnO}+2 \mathrm{OH}^{-}+\mathrm{H}_{2} \mathrm{O} \longrightarrow \mathrm{Sn}(\mathrm{OH})_{4}+2 \mathrm{e}^{-}
$$

in addition to the formation of the soluble stannate ions,

$$
\mathrm{Sn}+5 \mathrm{OH}^{-} \longrightarrow \mathrm{HSnO}_{3}{ }^{-}+2 \mathrm{H}_{2} \mathrm{O}+4 \mathrm{e}^{-}
$$

Dehydration of the thermodynamically unstable $\mathrm{Sn}(\mathrm{OH})_{4}$ to the corresponding stable $\mathrm{SnO}_{2}$ can occur on the tin electrode during the potential sweep to positive direction $^{(30)}$.

When the surface is covered with the passive film, the dissolution current falls to a small value, denoting the onset of permanent passivity. Previous works confirmed the duplex nature of the passive film which consisted of both $\mathrm{SnO}$ and $\mathrm{SnO}_{2}{ }^{(36)}$. From the relation between the potential and $\log \mathrm{i}$ (Tafel relation), the electrochemical parameters are reported in Table 2. 
Table (2): The electrochemical parameters of tin electrode in different concentrations of $\mathrm{NaOH}$ solutions

\begin{tabular}{|c|c|c|c|c|c|}
\hline \multirow{2}{*}{$\begin{array}{c}\text { Conc. } \\
\text { M }\end{array}$} & \multirow[b]{2}{*}{$\begin{array}{c}\mathbf{E}_{\text {corr. }} \\
\mathbf{m V}(\mathrm{SCE})\end{array}$} & \multirow[b]{2}{*}{$\begin{array}{c}\mathbf{i}_{\text {corr. }} \\
\mathbf{m A} / \mathrm{cm}^{2}\end{array}$} & \multicolumn{2}{|c|}{ Tafel Slopes } & \multirow{2}{*}{$\begin{array}{c}\text { Corrosion } \\
\text { rate } \\
\mathbf{m m} / \mathbf{y}\end{array}$} \\
\hline & & & $\begin{array}{c}\mathbf{B}_{\mathrm{a}}(\mathbf{m V} / \\
\mathrm{dec} .)\end{array}$ & $\begin{array}{c}B_{\mathrm{c}}(\mathrm{mV} / \\
\text { dec. })\end{array}$ & \\
\hline 2.0 & -1194 & 1.183 & 68.0 & -381.3 & 14.03 \\
\hline 1.5 & -1163 & 1.022 & 61.4 & -314.0 & 12.12 \\
\hline 1.0 & -1158 & 0.549 & 66.6 & -362.8 & 6.51 \\
\hline $5 \times 10^{-1}$ & -1145 & 0.370 & 85.3 & -449.8 & 4.42 \\
\hline $1 \times 10^{-1}$ & -1137 & 0.091 & 64.0 & -333.6 & 1.08 \\
\hline $1 \times 10^{-2}$ & -1093 & 0.042 & 66.0 & -293.0 & 0.50 \\
\hline $1 \times 10^{-3}$ & -846 & 0.037 & 217.0 & -313.0 & 0.44 \\
\hline $1 \times 10^{-5}$ & -797 & 0.005 & 0.3 & -347.0 & 0.06 \\
\hline
\end{tabular}

From the curves and Table 2 we can concluded that: increasing the concentration of $\mathrm{NaOH}$ solutions enhances the peaks current (corrosion current, $\mathrm{i}_{\text {corr. }}$ ), and the corrosion potential, $\mathrm{E}_{\mathrm{corr}}$, shift towards more negative values. Also corrosion rates were increased by increasing $\mathrm{NaOH}$ concentration.

By comparing the corrosion rates of the two test solutions it was illustrated that $\mathrm{NaOH}$ solutions are more corrosive than $\mathrm{H}_{2} \mathrm{SO}_{4}$ solutions (Figure 7). These results are in good agreement with those obtained in O.C.P. measurements.



Figure (7): Corrosion rates vs. concentration for:

$-\mathrm{H}_{2} \mathrm{SO}_{4}$ and $\square \mathrm{NaOH}$ solutions 


\section{Energy dispersive X-ray analysis [EDX]:}

It is important to take into consideration the percentages of elements present on the surface of the tin electrode. This was obtained from energy dispersive X-ray analysis (EDX) on $\mathrm{Sn}$ electrode in $1 \mathrm{M}$ of each of $\mathrm{H}_{2} \mathrm{SO}_{4}$ and $\mathrm{NaOH}$ solutions (Figures 8 and 9). The spectra showed that the percentages of elements present on the surface of tin electrode are as tabulated in Table (3).

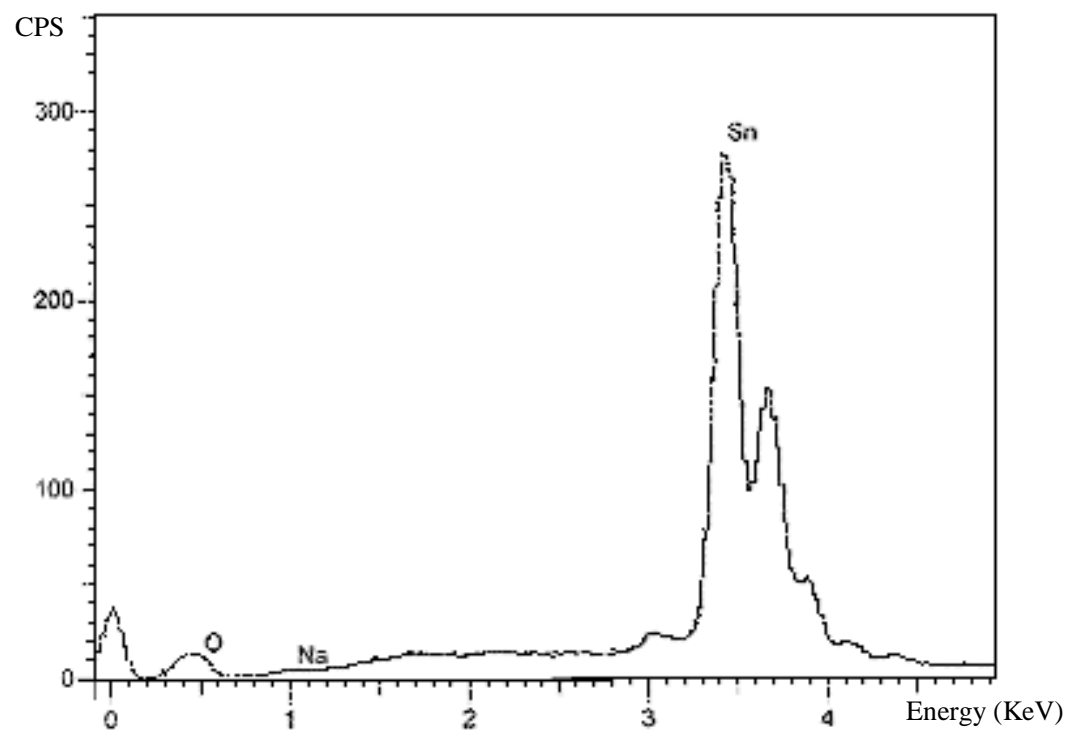

Figure (8): EDX spectra of Tin electrode in $1 \mathrm{M} \mathrm{NaOH}$

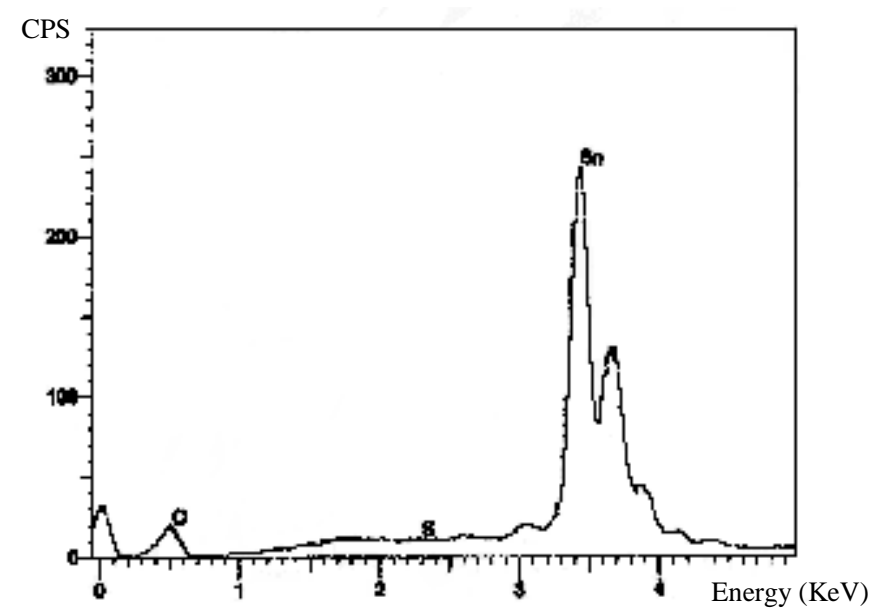

Figure (9): EDX spectra of Tin electrode in $1 \mathrm{M} \mathrm{H}_{2} \mathrm{SO}_{4}$ 
Table (3): The elements present on the surface of tin electrode

\begin{tabular}{ccccc}
\hline Media & Sn \% & $\mathbf{O}_{\mathbf{2}} \%$ & $\mathbf{S} \%$ & Na \% \\
\hline $1 \mathrm{M} \mathrm{NaOH}$ & 91.82 & 7.74 & - & 0.44 \\
$1 \mathrm{M} \mathrm{H}_{2} \mathrm{SO}_{4}$ & 83.52 & 16.33 & 0.15 & - \\
\hline
\end{tabular}

\section{Conclusion}

Tin is passivated in low concentrations of $\mathrm{H}_{2} \mathrm{SO}_{4}$ and $\mathrm{NaOH}$ solutions while at high concentrations, dissolution occurs in which the corrosivety of $\mathrm{NaOH}$ is higher than that of $\mathrm{H}_{2} \mathrm{SO}_{4}$ solutions. The studied solutions retard the corrosion of $\mathrm{Sn}$ as the concentration decreased and increase in concentration led to increasing the corrosion rates.

\section{References}

1. W.S. Jeon, C.C. Shur, J.G. Kim, S.Z. Han and Y.S. Kim; J. Alloys and Compounds, 455, (1-2), 2008, 358

2. M.A. Kiani, M.F. Mousavi, S. Ghasemi, M. Shamsipur and S.H. Kazemi; Corrosion Science, 50(4), 2008, 1035.

3. F. El-Taib Heakal, A.M. Fekry and A.A. Ghoneim; Corrosion Science, 50(6), 2008, 1618.

4. A. Pardo, M.C. Merino, M. Carboneras, F. Viejo and R. Arrabal, J. Muñoz; Corrosion Science, 48(5), 2006, 1075.

5. A.D. Pogrebnjak, Yu.A. Kravchenko, S.B. Kislitsyn, Sh.M. Ruzimov, F. Noli, P. Misaelides and A. Hatzidimitriou; Surface and Coatings Technology, 201(6), 2006, 2621.

6. D. López, C. Sánchez and A. Toro; Wear, 258, (1-4), 2005, 684.

7. J.R. Goldberg and J. L. Gilbert; Biomaterials, 25(5), 2004, 851.

8. The New Caxton Encyclopedia, Caxton publications limited London England part 18, 1983, 292.

9. C. Chiavari, A. Colledan, A. Frignani and G. Brunoro; Materials Chemistry and Physics, 95(2-3), 2006, 252.

10. Diez- Perez, F. Sanz and P. Gorostiza; Current Opinion in Solid state and Materials Science, 10 (3-4), 2007,144.

11. K.G. Gomma; Energetics; Chemistry Earth Environmental and Biomedical Problems, 50(1-3), 1995, 39.

12. C.M. Almeida, T. Raboczkay and B. F. Giannetti; J. Applied Electrochemistry, 29(1), $1999,123$.

13. S.S. Abd El-Rehim, S.M. Sayyah and M.M. El- Deeb; Materials Chemistry and Physics, 80(3), 2003, 696. 
14. S. S. Abd El-Rehim, H. H. Hassan and N. F. Mohamed; Corrosion Science, 46(5), 2004, 1071.

15. E.E. Foad El-Sherbini; J. Electroanalytical Chemistry, 584(2), 2005, 167.

16. S. S. Abd El Rehim, A. M. Zaky and N. F. Mohamed; J. Alloys and Compounds, 424(12), $2006,88$.

17. R. M. Abou Shahba, A. S. I. Ahmed, E. M. Attia and A. E. El- Shennawy; Al - Azhar Bulletin of Science. 18(2), 2007, 47.

18. M. Jafarian, F. Gobal, I. Danaee, R. Biabani and M.G. Mahjani; Electrochimica Acta, 53(13), 2008, 4528.

19. Al-Suhybani and A. Abdulaziz; Surface and Coatings Technology, 34(4), 1988, 463.

20. O.M. Kuznetsova, G.S. Saprykina and T.A. Vostryakova; Protection of Metals, 13(1), 1977, 109.

21. A. Abdulaziz and Al-Suhybani; British Corrosion J., 24(3), 1989, 204.

22. S. C. Britton and D. G. Michael; J. Applied Chemistry, 5, 1955, 1.

23. H. Barbre, C. Bagger and E. Maahn; Electrochimica Acta, 16, 1971, 559.

24. V. A. Khitrov and V. I. Shatalova; Zhur. Priklad Khim., 34, 1961, 2106.

25. A. M. Shams El-Din and F. M. Abd El-Wahab; Electrochimica Acta, 9, 1964, 883.

26. R.O. Ansell, T. Dickinson, A.F. Povey and P.M.A. Sherwood; J. Electrochemical Society, 124(9), 1977, 1360.

27. E.H. Ait Addi, L. Bazzi, M. Elhilali, Zine El-Alami, R. Salghi, and El-Issami Souad; Canadian J. Chemistry, 81(4), 2003, 297.

28. E.H. Ait Addi, L. Bazzi, M. Elhilali, R. Salghi, B. Hammouti and M. Mihit.; Applied Surface Science, 253(2), 2006, 555.

29. U.R. Evans; "An Introduction to Metallic corrosion", $3^{\text {rd }}$ Edition, Edward Arnold, London (1981).

30. M. Pourbaix; "Atlas of Electrochemical Equilibrium Diagrams in Aqueous solutions", NACE, Texas, 1966, 475.

31. M. Pugh, L. M. Warner and D. R. Gabe; Corrosion Science, 7, 1967, 807.

32. T. Ito and M. Abe; Kogyo Kagaku Zasshi, 63, 1960, 1699.

33. G. Gordon and C. H. Brubaker; J. American Chemical Society, 82, 1960, 4448.

34. M. Natesan and S. V. Iyer; Key - Engineering-Materials, 20-28(4), 1988, 531.

35. H. H. Hassan, S. S. Abd El-Rehim and N. F. Mohamed; Corrosion Science, 44(1), 2002, 37. 
36. K. Salmi and G. Sundholm; J. Power Sources, 40(1-2), 1992,217. 